\title{
Effect of superphosphate, lime, and cocksfoot on summer dry hill country pasture production
}

\author{
A.D. Mackay', R.W. Tillman', \\ W.J. Parker ${ }^{3}$ and D.J. Barker' \\ 'Grasslands Division, DSIR, \\ Private Bag, Pahnerston North \\ 2Department of Soil Science, and \\ Department of Agricultural and Horticultural Systems \\ Management, Massey University, Palmerston North
}

\begin{abstract}
Two long-term field trials were carried out in the Wairarapa. One, established on a resident ryegrass/browntop pasture in 1981, compared the effect of lime $(0,1.25,2.50$ and $5.00 \mathrm{t} / \mathrm{ha})$ and superphosphate $(0,125,250$ and $500 \mathrm{~kg} / \mathrm{ha})$ in a $4 \times 4$ factorial design. The second, started in 1985, compared the response of a similar pasture with that of au oversown 'Grasslands Wana' cocksfoot pasture to 4 rates of lime $(0,1.25,2.5$ and $5.0 \mathrm{t} / \mathrm{ha})$. The major effect of the traditional fertiliser policy was increased spring and, under favourable conditions, increased summer and autumn production. The introduction of cocksfoot guaranteed a more predictable summer supply of feed and improved autumn and winter production. An assessment of 3 methods of designating fertiliser expenditure suggests that continuation with maintenance fertiliser inputs, or a 2.3: 1 substitution of fertiliser expenditure for cocksfoot establishment, would provide greater benefits than discontinuing fertiliser inputs.
\end{abstract}

Keywords 'Grasslands Wana', cocksfoot, lime, superphosphate, fertliser, strategies, hill country

\section{INTRODUCTION}

Regular topdressing with superphosphate and lime to correct soil nutrient deficiencies have helped to improve the productivity of hill country pastures in New Zealand. However, in summer dry hill country, such as that in the Wairarapa, lack of moisture in summer and autumn, rather than soil fertility, restricts pasture growth (Radcliffe 1975). The introduction of a summer active, drought tolerant species, such as 'Grasslands Wana' cocksfoot (Dactylis glomerata L.), into this environment in conjunction with fettiliser may therefore be more successful in improving the seasonal supply of feed than continuing solely with a traditional fertiliser policy (Barker et al. 1985). Fertiliser use may then be more cost effective and farm profitability greater.
In this paper long-term field studies in the Wairarapa are used to compare the effect of a traditional fertiliser policy with the introduction of cocksfoot on the seasonal and annual supply of feed in summer dry hill country. The results are used to suggest management strategies for improving annual and within-year reliability of pasture production.

\section{MATERIALS AND METHODS}

Both field studies were conducted at Massey University's 'Riverside' property in the Wairarapa. Average annual rainfall is $1207 \mathrm{~mm}$ of which $20 \%$ and $16 \%$ falls in summer and autumn, respectively (Parker et al. 1989). High evapotranspiration rates reduce the effectiveness of rainfall during this period.

\section{Traditional fertiliser policy}

To evaluate the effect of a traditional fertiliser policy a 4 x 4 factorial lime $x$ superphosphate trial was laid down on 2 sites of moderate slope (15-20") in September 1981 . The 2 sites, with a resident sward of predominantly browntop (Agrostis tenuis), perennial ryegrass (Lolium perenne) and suckling clover (Trifolium dubium), were selected to provide predominantly northerly and southerly aspects, respectively. Soils are YGE/YBE integrades with a $\mathrm{pH}$ of 5.4 and Olsen P of 8. Superphosphate was applied to $3 \times 2 \mathrm{~m}$ plots at rates equivalent to 0,125 , 250 and $500 \mathrm{~kg} / \mathrm{ha}$ and lime at $0,1250,2500$ and $5000 \mathrm{~kg} / \mathrm{ha}$ in a $4 \times 4$ factorial design. Superphosphate has since been applied annually to each plot at the initial treatment rate during winter-spring, but lime has not been applied again. Except for periodic short term $(<1$ year) exclosure from livestock for the measurement of pasture production, the trial sites have been grazed according to the farm's normal management.

Pasture production was measured over 15 months, commencing mid December 1987. At each harvest, the frequency of which was based both on the amount of growth and time of year (season), two $0.25 \mathrm{~m}^{2}$ quadrats were cut by electric shears. The legume component of the sward was determined at each harvest by dissection. The entire trial site was then mowed to the same height in preparation for the next growth period. Plots were grazed by sheep in late August before winter production could be estimated, and yield data for this period are not presented. 


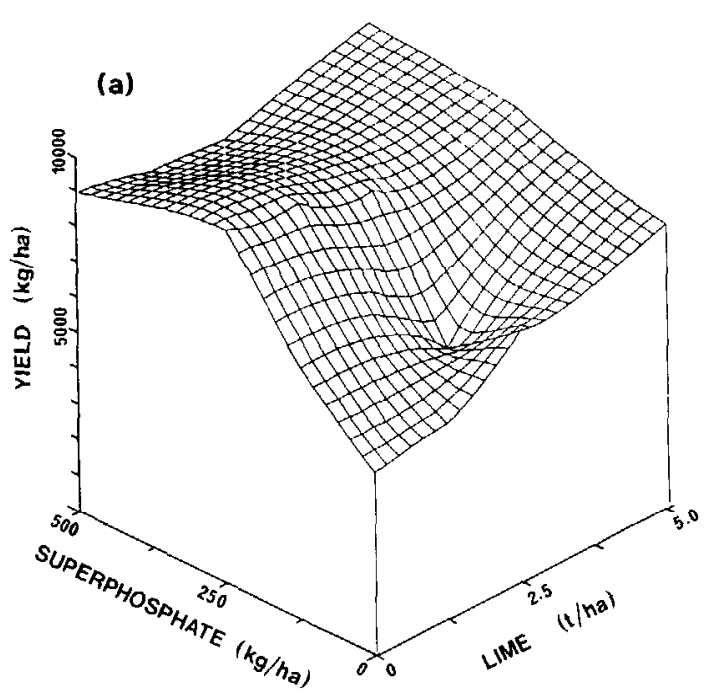

Figure 1 (a) Pasture and (b) legume dry matter response to superphosphate and lime.

\section{Establishment of cocksfoot}

To investigate the effect of a summer-active, drought-tolerant species in this environment, a cocksfoot sward was established in May 1985 on a moderate slope (10-25") with a predominantly westerly aspect. In March 1986 a lime trial was superimposed over the cocksfoot and adjacent resident sward. Lime was applied to $5 \times 18 \mathrm{~m}$ plots at rates equivalent to $0,1250,2500$ and $5000 \mathrm{~kg} /$ ha. The design was randomised split-plot with 4 replicates.

Pasture production was measured using exclusion cages $\left(0.5 \mathrm{~m}^{2}\right)$ over 15 months commencing in mid December 1987. Botanical composition, including cocksfoot, other grasses, legume and other species, was measured by dissection at each harvest. The trial site was grazed according to the farm's normal management. At establishment in 1985 Olsen $\mathrm{P}$ was 20. No superphosphate has been applied since then.

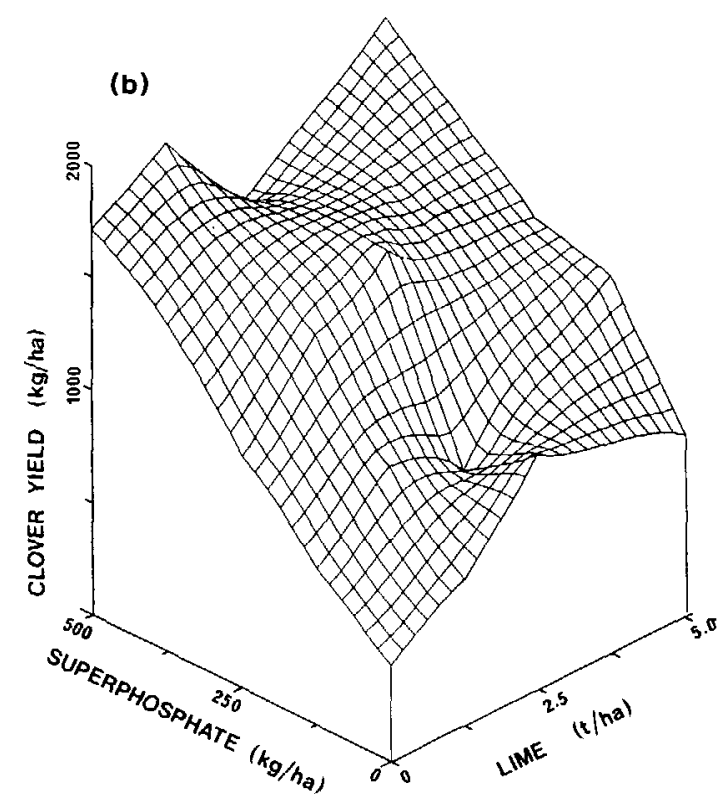

\section{RESULTS AND DISCUSSION}

\section{Traditional fertiliser policy}

Annual production Withholding superphosphate for 6 years decreased pasture production by $30 \%$ and legume production by $45 \%$ compared with plots dressed annually with $250 \mathrm{~kg} / \mathrm{ha}$ of superphosphate (Figure 1). Dressings above $250 \mathrm{~kg} / \mathrm{ha}$ produced little additional growth (Figure 1), indicating that an annual application of superphosphate at $250 \mathrm{~kg} / \mathrm{ha}$ is at or near maintenance for maximum production for this site. Superphosphate at $125 \mathrm{~kg} / \mathrm{ha}$ only slightly boosted legume and pasture production (Figure 1). There was a consistent increase in production with increased lime application rate, but this was much smaller than for superphosphate and was not statistically significant (Figure 1). The single application of $5 \mathrm{t}$ lime/ha, in $198 \mathrm{1}$, appears to have minimised the decline in pasture production associated with withholding superphosphate (Figure la), although the poor legume growth (Figure lb) shows this approach does not offer a long-term solution for maintaining productivity.

Table 1 Pasture and legume responses (kg DM/ha) to lime and superphosphate inputs.

\begin{tabular}{|c|c|c|c|c|c|}
\hline \multicolumn{2}{|c|}{ Fertiliser policy } & \multicolumn{4}{|c|}{ Pasture production } \\
\hline $\begin{array}{l}\text { Superphosphate } \\
\text { (kg/ha/yr) }\end{array}$ & $\begin{array}{c}\text { Lime } \\
\text { (kg/ha) }\end{array}$ & $\begin{array}{r}\text { Summer } \\
(1987 / 88) \\
\end{array}$ & $\begin{array}{c}\text { Autumn } \\
\text { (1988) }\end{array}$ & $\begin{array}{l}\text { Spring } \\
(1988)\end{array}$ & $\begin{array}{r}\text { Early summer } \\
(1988 / 89)\end{array}$ \\
\hline 0 & & $2786 \quad(352)$ & $800 \quad(69)$ & $1030 \quad(97)$ & 1719 (209) \\
\hline $12 s$ & & $3027(495)$ & 984 (115) & 1046 (110) & 1896 (238) \\
\hline 250 & & $3866 \quad(710)$ & 1248 (133) & $1511(180)$ & 2797 \\
\hline 500 & & $3835(910)$ & 1154 (187) & 1239 (191) & 2618 \\
\hline & 0 & 3163 (459) & $1010(90)$ & $1226(117)$ & 2314 \\
\hline & 1250 & (673) & $1053(101)$ & $1216(165)$ & $2027 \quad(282)$ \\
\hline & 2500 & $(610)$ & $999(138)$ & $1132(140)$ & 2157 \\
\hline & 5000 & 3923 (725), & 1123 (147) & 1252 (156) & 2532 \\
\hline & $\mathrm{LSD}_{0.0 \mathrm{~s}}$ & N.S. (317) & 221 & 263 & 492 (209) \\
\hline
\end{tabular}

'Legume production. 
Seasonal production Compared with the very positive effect of an annual maintenance dressing of superphosphate $(250 \mathrm{~kg} / \mathrm{ha})$, a half maintenance rate $(125 \mathrm{~kg} / \mathrm{ha})$ had a minor effect on the seasonal supply of feed and legume growth (Table 1). Additions of superphosphate above $250 \mathrm{~kg} / \mathrm{ha}$ had little added benefit. The effect of not applying superphosphate was detrimental in all seasons, particularly legume growth in spring and summer (Table 1). Seasonal increases in legume production with increased lime (Table 1) were consistent but not statistically significant.

\section{Performance of cocksfoot}

Annual production In the absence of applied lime, the cocksfoot sward produced $13 \%$ more DM than

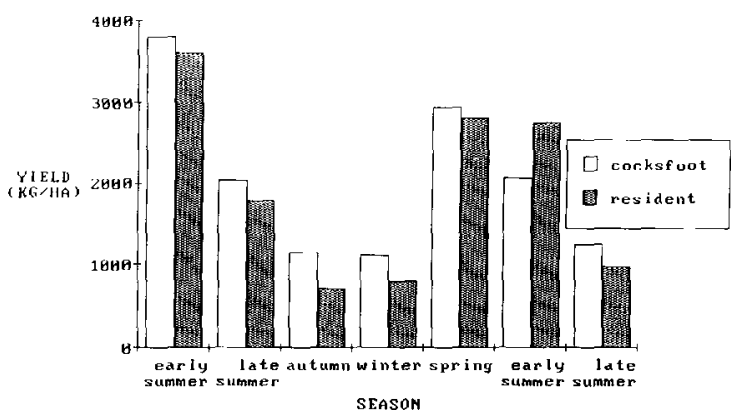

Figure 2 Dry matter production of resident and cocksfoot sward in the 12 months of measurement.

the resident sward over the 12 months (Figure 2) and on average $18 \%$ more than the resident sward in the previous 3 years (Mackay et al. 1987). Compared with more than $20 \%$ variation in annual production of the resident sward in the previous 3 years, the variation in annual production with cocksfoot over the same period was less than $10 \%$. In November 1988, Olsen P on the resident sward had declined to 16 , and on the cocksfoot sward to 13 , reflecting the greater production off this area. The poorer P status of the cocksfoot sward is also reflected in reduced legume production (Table 2). To maintain the advantages offered by cocksfoot some super-phosphate is apparently required.
Seasonal production The cocksfoot sward outperformed the resident sward in the late summer, autumn and winter of 1988 by 14,44 and $43 \%$, respectively, and in the late summer of 1989 by $44 \%$ (Figure 2). During the previous summer $(1987 / 88)$, which was atypically wet for the Wairarapa (more than $350 \mathrm{~mm}$ falling throughout February to March), production of the resident and cocksfoot swards was similar (Figure 2). However, the clearly superior performance of the cocksfoot sward going into the very dry summer of 1989 , demonstrates the potential benefits of this summeractive species.

\section{Management strategies}

Fertiliser is the major item of discretionary expenditure on hill country farms. The data from the two field studies enable the effect of alternative designation of fertiliser expenditure on seasonal and annual feed supply, and financial returns, to be broadly assessed.

1. Discontinue fertiliser application Sole reliance on existing soil $\mathrm{P}$ reserves slowly reduces annual production $(5 \% / y)$ and reduces legume production more rapidly (Figure 1 ). Stock numbers will have to decline to maintain performance per animal. The immediate advantage of reduced input costs has to be balanced against the initial levels of soil fertility and the long-term $>3-4$ years) reduction in returns, due to falling animal production. Furthermore, poor pasture responses to applied fertiliser can be expected on the resumption of topdressing (Mackay \& Wewala 1989). Applying lime (5 t/ha) offers some scope for slowing the decline in production per ha, but the high initial cost ( $\$ 195 / \mathrm{ha})$ rules this out for farmers already short of cash.

\section{Maintenance applications of superphosphate} An annual maintenance application of superphosphate improves spring production, and in years of favourable growth increases summer and autumn production (Table 1) compared with no fertiliser. The resulting improvement in legume content

Table 2 Components and total production ( $\mathrm{kg} \mathrm{DM} / \mathrm{ha}$ ) on the resident and cocksfoot sward.

\begin{tabular}{lrrrrrr}
\hline Sward & $\begin{array}{c}\text { Lime } \\
\text { application } \\
\text { (kg/ha) }\end{array}$ & Cocksfoot & $\begin{array}{c}\text { Other } \\
\text { grasses }\end{array}$ & Legume & $\begin{array}{c}\text { Other } \\
\text { species }\end{array}$ & Total \\
\hline Resident & $\mathbf{0}$ & 96 & 8906 & 1478 & 1358 & 11840 \\
& 1250 & 322 & 9368 & 1692 & 1019 & 12403 \\
& 2500 & 382 & 10188 & 2283 & 1022 & 13875 \\
Cocksfoot & 5000 & 272 & 10329 & 2117 & 1264 & 13983 \\
& 0 & 5074 & 6403 & 1090 & 776 & 13344 \\
& 1250 & 5296 & 6829 & 971 & 824 & 13921 \\
& 2500 & 4580 & 6971 & 1354 & 772 & 13679 \\
& 5000 & 6043 & 6190 & 1080 & 740 & 14654 \\
& LSD, 05 & 1193 & 730 & 664 & 420 & 2277 \\
\hline
\end{tabular}


(Figure 1) is especially important for the rearing of young stock. Higher growth rates in these animals can allow earlier sale of non-replacements and so reduce stocking rate before the drier summer months. In years of favourable weather animals can be carried to heavier weights before slaughter. Returns will therefore be increased directly through the sale of heavier animals or through higher priced early-season sales, and indirectly through improved flock performance resulting from better quality replacements entering the flock.

3. Substitution of superphosphate expenditure for the establishment of drought tolerant cultivars The purpose of expenditure substitution is to allow farmers with tight liquidity to maintain a sustainable cashflow during the period of new cultivar establishment. In 1988/89 the equivalent of $250 \mathrm{~kg}$ superphosphate cost $\$ 65 /$ ha to apply aerially. Introduction of cocksfoot $(10 \mathrm{~kg}$ 'Grasslands Wana' seed/ha) using herbicide (3-4 paraquat/ha) over-sowing and trampling (Barker \& Zhang 1988) cost $\$ 150 /$ ha. The substitution rate was therefore 2.3: 1. The introduction of a large area of new cultivar at any one time is not favoured because of the short-term loss of pasture production and the additional grazing management requirement during establishment. Maintenance fertiliser applications therefore need be withheld from only a small part of the farm. While the initial establishment costs are high, and short-term cash flow requirements are likely to be a major consideration in the decision to proceed (Frengley \& Anderson 1989), this expenditure nevertheless represents a long-term investment, and benefits will accrue over the lifetime of the improved sward.

Our results indicate that the expectation from substitution should be related to the base levels of soil fertility. Greater production by the introduced cultivar will deplete soil reserves more rapidly, and reintroduction of fertiliser will eventually be required to prevent a decline in sward legume content (Table 2).

\section{SUMMARY AND CONCLUSIONS}

A comprehensive evaluation of fertiliser use is complicated (Scobie \& St Pierre 1987), but the annual profitability of the three strategies can be estimated simply by feed budget and gross margins analysis (Cameron 1987). If a ewe (1 su) consumes $550 \mathrm{~kg} \mathrm{DM} / \mathrm{y}$ (Rattray 1978) and $80 \%$ of the additional pasture grown (excluding winter) because of the application of fertiliser is utilised, an additional $7 \mathrm{su} / \mathrm{ha}$ could have been supported during 1988 on the plots receiving $250 \mathrm{~kg}$ superphosphate annually (and without the initial input of lime) compared with those receiving no phosphate (Figure 1). Additional income (Gross margin $=\$ 20-30 /$ su) easily compensates for the cost of fertiliser (\$65/ha) $y \div 7$ su $=\$ 9.29$ su/y). Similarly, the cocksfoot sward (without lime) grew sufficient extra production to support $2.2 \mathrm{su} /$ ha more than the resident sward (Table 2). If the cost of establishment $(\$ 150 / \mathrm{ha})$ was borrowed at an interest rate of $14 \%$ over 20 years (the assumed life of the sward), the equivalent cost of establishment is $\$ 22.65 /$ ha. At least one additional su/ha on the cocksfoot area is therefore required to meet establishment costs, and some extra expenditure will be required for maintenance fertiliser in 3-4 years time. In compensation, there will be less risk to animal production during dry summers and autumns, and this should improve animal performance and returns. On balance, regular maintenance topdressing at present appears to be the most profitable option. However, the effect of resumed topdressing on cocksfoot production is unknown, and is under investigation.

Acknowledgements To Neil Kilmister and the Riverside farm staff, Venessa Pokaia, the ladies in the herbage dissection laboratory, and the Mauriceville Lime Company for supplying lime.

\section{REFERENCES}

Barker, D.J.; Lancashire, J.A.; Meurk, C. 1985. 'Grasslands Wana' cocksfoot - an improved grass suitable for hill country. Proceedings NZ Grassland Association 46 167-172.

Barker, D.J.; Zhang, D.M. 1988. The effects of paraquat spraying, seed placement, and pre-germination on the appearance and survival of white clover, cocksfoot, and ryegrass seedlings from spring oversowing in hill country. NZ Journal of Experimental Agriculture 16: 1.9.

Cameron, I.H. 1987. 'Superate' - a new method for objectively predicting the best superphosphate rate for pasture in Victoria. In. Temperate Pastures; their production, use and management. Australian Woo Corporation Technical Publication/CSIRO: 137-1 39.

Frengley, G.A.G.; Anderson, C.J. 1989. Pragmatism in hill pasture renovation. Procedings of the NZ Grassland Association 50: 151-156

Mackay, A.D.; Wewala. G.S. 1989. Evaluation of partially acidulated phosphate fertilisers and reactive phosphate rock for hill pastures. Fertiliser Research 16 (in press),

Mackay, A.D.; Barker, D.J.; Tillman, R.W. 1987. Riverside Annual Review 1986/87. Riverside Farm Publication, Massey University No. 13: 23-25.

Parker, W.J.; Tillman, R.W.; Gray, D.I. 1989. Management considerations in nitrogen fertiliser usage on a Wairarapa sheep farm. Proceedings of the Workshop on 'Nitrogen in New Zealand Agriculture and Horticulture', Occasional Report No. 3, Fertiliser and Lime Research Centre, Massey University: 65-78.

Radcliffe. J.E. 1975. Seasonal distribution of pasture production in New Zealand. VII. Masterton (Wairarapa) and Maraekakaho (Hawke's Bay). NZ Journal of Experimental Agriculture 3: 259-265.

Rattray, P.V. 1978. Pasture constraints to adult sheep production. Proceedings of the Agronomy Society 8: 103-108.

Scobie, G.M.; St Pierre, N.R. 1987. Economics of nhosnhonis fertiliser use on pastures. 1. Long-run maintenance requirements. NZ Journal of Agricultural Research 15: 435-443. 